\title{
OUTWARD FDI AND ITS IMPLICATION ON INDONESIAN DOMESTIC INVESTMENT
}

\author{
Tutik Wiryanti Gondo ${ }^{1}$, Tajul Ariffin Masron ${ }^{2 *}$, Haslindar Ibrahim², \\ and Nik Hadiyan Nik Azman ${ }^{2}$ \\ ${ }^{1}$ Faculty of Economy and Business, M.H. Thamrin University, Jln. Raya Pondok Gede \\ No. 23-25, Kramat Jati, Jakarta, Indonesia \\ ${ }^{2}$ School of Management, Universiti Sains Malaysia, 11800 USM Pulau Pinang, Malaysia \\ *Corresponding author: tams@usm.my
}

Published online: 4 June 2021

To cite this article: Gondo, T. W., Masron, T. A., Ibrahim, H., \& Nik Azman, N. H. (2021). Outward FDI and its implication on Indonesian domestic investment. Asian Academy of Management Journal, 26(1), 143-169. https://doi.org/10.21315/aamj2021.26.1.6

To link to this article: https://doi.org/10.21315/aamj2021.26.1.6

\begin{abstract}
Since becoming a democratic country in the late 1990s, Indonesia has been changing into a more promising countries with a remarkable reduction in poverty by more than $50 \%$ during the last decade. To achieve a developed or high-income country, Indonesia must grow by $8 \%$ to $9 \%$ annually with huge investment is needed in every sector, ranging from infrastructure to human development in the digital era. Apart from strengthening tax revenue collection, Indonesian government must also investigate the role of outward foreign direct investment (OFDI) that potentially affects domestic investment in the negative way. Hence, it is the objective of this study to examine the impact of OFDI on Indonesian domestic investment for the period between 1980 and 2018. By applying vector error correction model, we observe that OFDI has significant adverse effect on domestic investment. With current inflows of foreign direct investment (FDI) has also never reached to the level prior to the 1997 economic crisis, discouraging the outflows of FDI could be a desirable strategy.
\end{abstract}

Keywords: outward FDI, domestic investment, Indonesia, time series analysis, divestment

\section{INTRODUCTION}

Rate of capital formation will have a strong effect on economic growth rate (Levine $\&$ Renelt, 1992). With generally low fund available in developing countries, foreign

(C) Asian Academy of Management and Penerbit Universiti Sains Malaysia, 2021. This work is licensed under the terms of the Creative Commons Attribution (CC BY) (http://creativecommons. org/licenses/by/4.0/). 
direct investment (FDI) could be the most important source of fund of domestic capital formation. ${ }^{1}$ Many studies have confirmed the growth-enhancing role of FDI to host countries, either in the case of developed (Barrell \& Pain, 1997; Freckleton et al., 2012) or developing countries (Balasubramanyam et al., 1996; Borensztein et al., 1998; Yao \& Wei, 2007; Alguacil et al., 2011). Particularly, capital-poor developing countries can be better-off in the long run if they can eschew foreign capital, especially FDI (Firebaugh, 1992). Regardless of the benefits of inflows of FDI, ${ }^{2}$ which was mainly in the past coming from developed countries, the recent trend shows that developing countries have also been growing as the new sources, or capital providers of FDI at global level. In 1995, outward foreign direct investment (OFDI) from developing countries constituted merely $4 \%$ of global FDI flows. However, the share in 2015 has reached a record of one-fifth of global FDI. Moreover, more developing countries have offered FDI in the recent list of contributors. With less than 90 developing countries were marginally involved in OFDI in 1990s, the list has risen to 109 countries, with 26 of these countries are having an OFDI-to-GDP ratio of $10 \%$ or more, today. While OFDI may signal the growing strength of firms in many developing countries economically, but the leakage of investment fund from domestic market may dampen the progression of economic development of the home developing countries.

Figure 1 highlights the pattern of domestic investment in the selected Asian countries, Indonesia, and its neighbouring countries. ${ }^{3}$ What can be justified from Figure 1 is the remarkable level of domestic investment prior to the 1997 Asian economic crisis, particularly Malaysia and Thailand. These two countries recorded the highest level of domestic investment, surpassing relatively developed South Korea in the third place. Indonesia generally does not show a consistent pattern of domestic investment. Nevertheless, Indonesian domestic investment remains at fourth place after South Korea before the wake of the 1997 Asian economic crisis, which is in better position than the uprising new economies of Vietnam and India. However, it falls into the last place immediately after the crisis and took more than 10 years for Indonesia to be able to recover the level of domestic investment just before the crisis. Interestingly, in the recent years, Indonesia has been at the top level relative to other Asian countries, completely in contrast to the sharp drop in domestic investment in Malaysia and Thailand. 


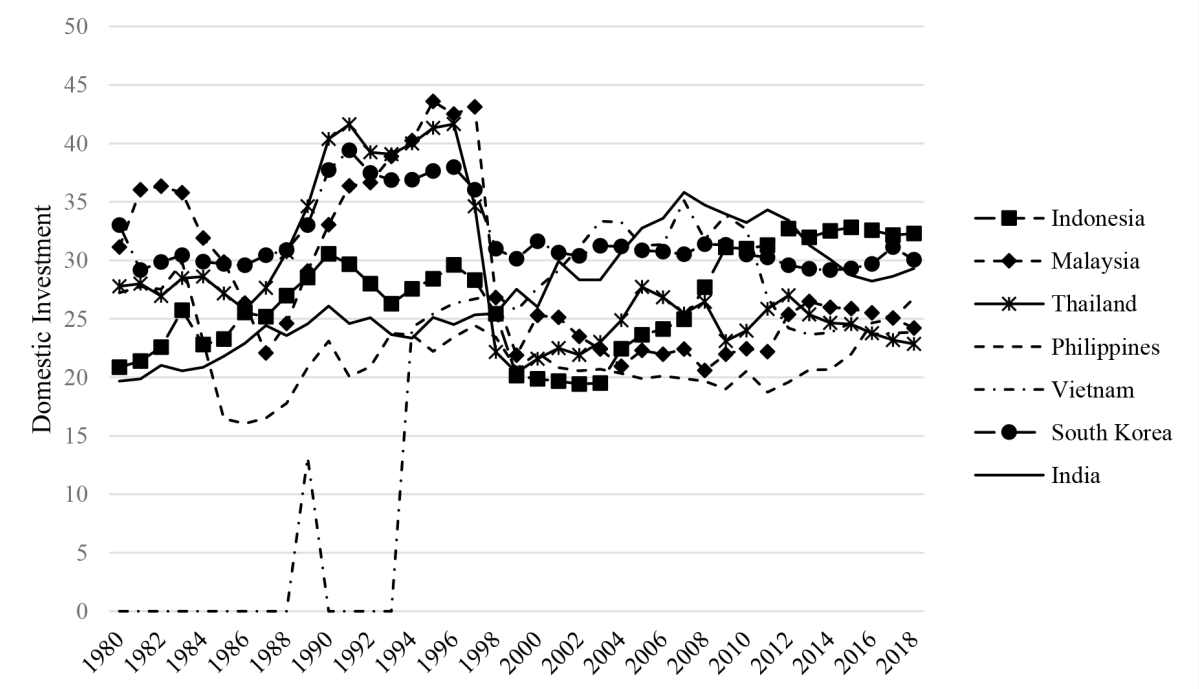

Figure 1. Domestic investment (as in \% of GDP) in the selected Asian countries Note: Domestic investment is represented by gross fixed capital formation. Poor information on domestic investment in Vietnam prior to 1994 should caution as the reading of the figure should only be valid from 1994 . Source: World Bank (2019)

With the pattern of domestic investment as shown in Figure 1, we are curious about the source of Indonesia's domestic investment behaviour. Among the primary sources of domestic investment is inward FDI (IFDI) from multinational corporations (MNCs) and credit by domestic financial institutions, while the leakage could come from OFDI. Interestingly, the take-off of Indonesian economy in 1980s, which is partly due to the IFDI but surprisingly is accompanied also by uprising outflow of FDI from Indonesia. Nothing much has been mentioned in the past studies regarding OFDI from Indonesia, but referring to high income inequality in Indonesia, we suspect this could be due to low prospect of growth in Indonesia and the rich are seeing more opportunities overseas. Throughout 1980s also we could see that the highly expected IFDI did not helpful with limited inflows recorded. ${ }^{4}$ The sharp decline in IFDI is fortunately shadowed by low but still positive OFDI from Indonesia. Combination of both low IFDI and positive OFDI could explain why Indonesia took more than 10 years to recover from crisis. Meanwhile, high IFDI and almost zero OFDI might explain why Indonesian domestic investment is currently at the highest relative to other six Asian countries to strongly support Indonesian economic development. 


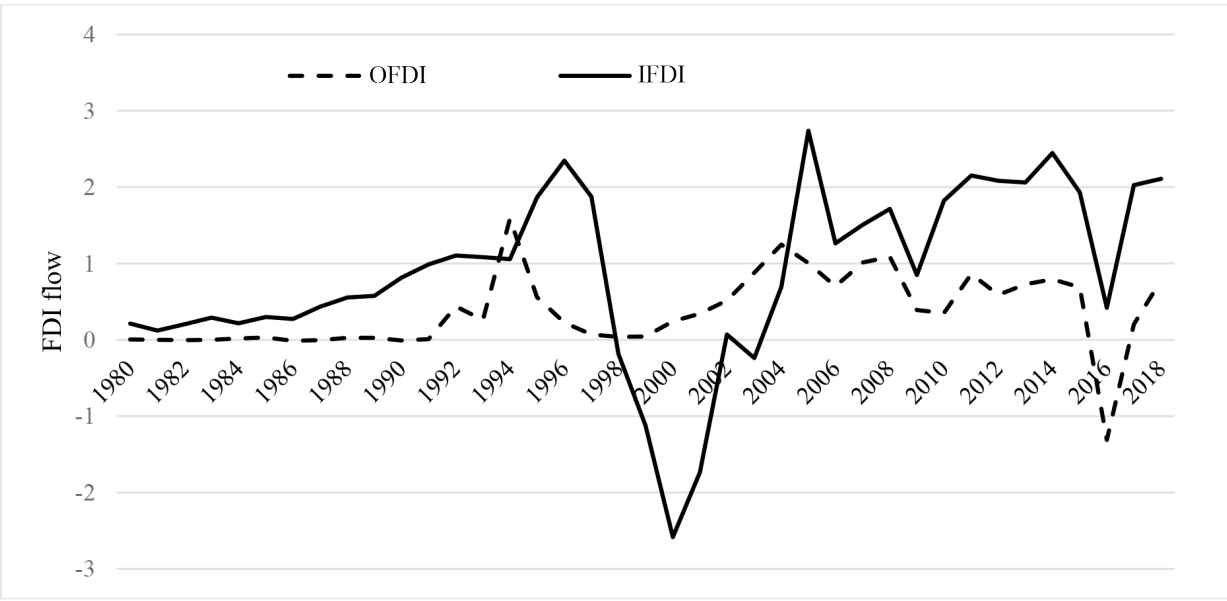

Figure 2. OFDI and IFDI (as in \% of GDP)

Source: World Bank (2019) and UNCTAD (2019)

One interesting point to note from Figure 2 is about the behaviour between OFDI and IFDI. Both are generally moving together in the same direction. For instance, between 1993 and 1997 Indonesia enjoyed huge inflows of FDI and at the same time OFDI also reached its peak. Similarly, between 2004 and 2016, high and positive IFDI was accompanied by positive close to $1 \%$ outflows of FDI from Indonesia. Although the recent slump in FDI inflows in 2017 was also followed by negative outflows of FDI by Indonesian, the latest surged in IFDI is also closely matched by resurgence of OFDI. With domestic investment is badly needed to rebuild Indonesian economy, the strategies to improve domestic investment could not be limited on encouraging more FDI inflows. The strategy should also include on how to discourage OFDI from Indonesia if the outflows are significantly large to deter economic development in Indonesia. Nevertheless, whether discouraging OFDI would be a desirable strategy, it depends on its implication on domestic investment. Hence, it is the objective of this study to examine the effect of OFDI from Indonesia on Indonesian domestic investment.

\section{LITERATURE REVIEW}

\section{GDP vs. Domestic Investment}

Theoretically, domestic investment has been one of four core components of gross domestic product (GDP). More investment is expected to bring in more GDP or economic growth. As more investment done by businesses, as their businesses expanded, more employment opportunities created, each worker will earn more 
and more demand will take place. Eventually, GDP will increase. Investment in capital and research and development (R\&D), in which technology is embedded will particularly be vital to long run economic growth. In fact, investment can also be done on human capital development, which will bring more talent for future innovation and therefore, induce higher GDP in the future. Using multiplier effect, simple investment in various economic activities creates more than proportionate amount of increment in GDP. For instance, Green (1997) observes that residential investment causes GDP, and not vice versa. ${ }^{5}$

On the other hand, under the perfect mobility assumption, Feldstein and Horioka (1980) predict that there will be no relationship between saving and investment. ${ }^{6}$ Although this argument has received support from Herwartz and $\mathrm{Xu}$ (2009), studies such as Miller (1988), De Vita and Abbott (2002), and Ang (2007) find contradicting results that saving has strong implication on domestic investment. Following the work of Solow (1956) and subsequently confirmed by several studies such as Bosworth (1993), Alguacil et al. (2004), and Romm (2005) that saving has a strong connection with economic growth, this could be one channel through which GDP will affect domestic investment.

\section{Financial Development vs. Domestic Investment}

While the debate on the comparative merits between bank-based financial development and stock-market based financial development in mobilising resources and eventually promoting high economic growth is going on (Levine, 2002; Ndikumana, 2005), each sectoral development is crucial to economic development by enhancing domestic investment. ${ }^{7}$ Theoretically, bank-based financial system can function as financial intermediary to allow entrepreneurs to invest more domestically. Banks offer financial assistance to alleviate financial constraints, particularly if firms are facing growth with growing demand. Business expansion may likely be possible via additional funding from banks, alongside own capital (Ndikumana, 2005). Ndikumana (2005) outlines several reasons of the benefits of banking system. First, lower cost of borrowing as financial intermediaries can exploit economies of scale, given huge collection of funds from depositors. Second, liquidity risk of investment can be minimised, if not fully avoided. Bank will do the long-term investment on behalf of depositors with the option to be able to withdraw in the short period. Third, banks can closely monitor the prospective investment against the low return risky investment easily, and later will focus more on assisting the promising investments or firms. By doing so, it is expected that firms' performance can be enhanced and more re-investment will be done by the firms. Hence, domestic investment will grow. ${ }^{8}$ 
On the empirical evidence, Ndikumana (2000) finds that financial development is crucial to domestic investment in sub-Saharan Africa. This finding is robust based on several indicators such as credit to the private sector, total liquid liabilities, credit provided by banks, and an index combining all three. In other words, financial development helps in future domestic investment via facilitating the allocation of financial resources towards the most promising domestic investment activities. Dutta and Roy (2009) present the analysis, in which the findings suggest that financial development has huge potential to boost domestic investment, provided it is supported by well-functioning financial system. ${ }^{9}$ Since low cost of acquiring information and doing transaction have been the primary target of investors, the emergence of sound financial market certainly demanded by the investors. In other words, growing domestic investment will concurrently request various financial facilities such as hedging, diversifying, risk pooling, and many other facilities. Hence, further development of financial system may also provide incentives for more domestic investment.

\section{IFDI vs. Domestic Investment}

As capital is one of the important elements in growth theories, either classical or neoclassical, inflows of foreign investment such as FDI will then be contributing to the accumulation of capital necessary to support economic growth. However, several past studies have argued that the role of foreign capital could be reversed. For instance, London and Robinson (1989), Boswell and Dixon (1990), and Wimberley (1991) document the case that economic dependency (often refers to heavy reliance on foreign investment) may adversely affect economic growth of the country. Firebaugh (1992) outlines five reasons for this. First, with the ability to avoid tax via transfer pricing, MNCs will contribute less to host government revenue. Second, given the huge gap in capability between MNCs and local firms, the development of indigenous or local entrepreneurship might be crashed out as stiff competition may put local entrepreneurs' survival in stake. Third, although local firms are expected to gain from technology transfer, MNCs normally will only bring its outdated technology to host country. In other words, MNCs may only bring inappropriate capital-intensive technology and therefore, minimise the level of benefits that host country supposed to obtain. Fourth, MNCs also are less likely to reinvest their profit in host country. Firm expansion might be done via local credit, rather than profit reinvestment. Finally, domestic firms are more likely to have strong linkage with other domestic firms, rather than with MNCs. The second issue is the main focus of this study, in which IFDI is crowding out or in domestic investment. ${ }^{10}$ 
Mišun and Tomšk (2002), who study similar issue in transition economies (or Central and Eastern European economies) observe both crowd-in and crowd-out effect of FDI on domestic investment. There is evidence of crowding-out effect for the period of 1990 and 2000 in Poland, while in the Czech Republic and Hungary, crowding-in effect is observed for the period between 1993-2000 and 1990-2000, respectively. According to Mišun and Tomšk (2002), FDI that offers new goods and services will generally create positive effect on domestic capital formation. Interestingly, the effect of FDI will also be significantly larger if the distribution of FDI is extremely different from the distribution of existing (mainly local firms') capital stock. ${ }^{11}$ Conversely, if the MNCs are venturing into the areas where local firms are also focusing at, then increasing competition may crowd-out local firms from the business areas due to less competitive than MNCs. In other word, if FDI is also distributed at the similar locations or sectors, then, the crowd-out effect can be expected.

Empirically, the recent study by Jude (2019) in the case of 10 Central and Eastern European countries demonstrates that crowding-out effect is only a short-run phenomenon explained by creative destruction framework. IFDI tends to crowd-in more investment in the long run with greenfield being the primary channel through which FDI promotes more domestic investment. Prior to Jude (2019), Pilbeam and Oboleviciute (2012) also find similar finding that in the 26 new European Union (EU) members, FDI does not exert crowding-out effect on domestic investment. However, the crowding-out phenomenon occurs in the older 14 EU members for the period 1990-2008. Mutenyo and Asmah (2010) find a reverse sign of crowdingout effect of FDI on domestic investment in 34 sub-Saharan African countries over the period 1990-2003. Apergis et al. (2006) find a crowding-in effect in the less advanced countries in Asia and Africa. In the case of more developed countries, namely the United States and European countries, crowding-out effect is dominating. In a more similar fashion, Mileva (2008) demonstrates that crowdingin effect or positive spill-over effect can be seen in the transition economies of the new EU members.

On the reverse causality, domestic investment may also mean government has successfully created a good business environment, which not only conducive for domestic firms but also to MNCs. High domestic investment also indicates that the host country is well prepared with supporting firms that may be needed to be part of the supply networking. Hence, country with impressive inflows of FDI may also be successful in creating more domestic investment in the host country. 


\section{OFDI vs. Domestic Investment}

Steven and Lipsey (1992) highlight two channels which OFDI may affect domestic investment. First, via the shift or transfer of domestic saving to foreign market. With limited private-domestic saving, firms facing financial constraint might not be getting the financial liquidity needed from financial institution. Scarcity of financial resources will make it harder to get financial assistance from the domestic financial markets. In the nutshell, OFDI may dampen domestic investment by diverting domestic resources to overseas project. This is particularly exerting much stronger effect if: (1) the expansion abroad is fully financed by using firms' internal resources, and (2) the partial of annual profits is not retuned to or reinvested at home countries for domestic expansion. Second, depending on the motive of moving firms' production line abroad, OFDI may exert an effect on domestic investment. The first motive of efficiency-seeking may not lead to reduction in domestic investment. This strategy which refers to relocation of certain production line abroad, referring to Hejazi and Pauly (2003), may not be affecting domestic investment negatively, or at least neutral. Rather, it may promote rate of domestic investment given by more MNCs' exports of capital and intermediate goods to host countries. The second motive of OFDI, which is market-seeking orientation may have similar effect to efficiency-seeking motivation. The effect could be neutral if displacement of production facilities to overseas does not involve full movement of the production from home country. If at home country export production of finished goods is still going on, then domestic investment will remain. However, even if the shift of production facilities is in full size, if the new demands for intermediate inputs from parent company or other domestic firm continue, then the result of crowd-in or crowd-out effect is ambiguous. Finally, in the case of strategic asset-seeking OFDI, this type of OFDI is expected to bring in a positive effect as the new knowledge might be sent back to home country. Parent company can then apply the new techniques to upgrade its productivity and product uniqueness.

On the empirical side, Feldstein (1995) examines the OFDI from the Organisation for Economic Co-operation and Development (OECD) countries in 1970s and 1980s and observes that OFDI has crowded out domestic investment. Similar findings found by Sauramo (2008) for Finland and Herzer and Schrooten (2007) for Germany. On the other side, Desai et al. (2005) observe that there is no evidence to suggest that outward FDI from the United States exerts negative effect on domestic investment. Among the crucial explanations for this is that the combination of production within and outside the United States has helped the United States MNCs to enjoy lower cost of production. At every level of production, profit is materialised and therefore, domestic as well as abroad investment are growing simultaneously. On the reverse causality, stronger domestic investment may mean 
high competition for capturing domestic market. Hence, pushing some firms to move overseas to capture new market niche, particularly in the countries that can offer new advantages such as cheap labour and other resources. Alternatively, it may also mean domestic firm has grown stronger and capable to compete at global level. In summary, there could be a bidirectional causality between OFDI and domestic investment.

\section{METHODOLOGY}

Following the work of Fry (1988), the accelerator model assumes that the desired capital stock $\left(K^{*}\right)$ is proportional to real output $y$ :

$$
K^{*}=\alpha y
$$

Equation 1 can be expressed in terms of desired ratio of net investment to output $(I / Y)^{*}$ :

$$
(I / Y)^{*}=\alpha \gamma
$$

where $\gamma$ denotes the growth rate of output. The partial adjustment mechanism specified for the investment ratio is to allow the actual investment to adjust partially in any one period to the difference between the desired investment ratio and the investment ratio in the previous period:

$$
(I / Y)=\lambda\left[(I / Y)^{*}-(I / Y)_{t-1}\right]
$$

or

$$
I / Y=\lambda(I / Y)^{*}+(1-\lambda)(I / Y)_{t-1}
$$

where $\lambda$ is the coefficient of adjustment. The flexible accelerator model allows economic conditions to influence the adjustment coefficient $\lambda$. Specifically,

$$
\lambda=\beta_{0}+\left[\frac{\beta_{1} z_{1}+\beta_{2} z_{2}+\beta_{3} z_{3}+\ldots}{(I / Y)^{*}-(I / Y)_{t-1}}\right]
$$

where $Z_{i}$ are all the variables (which include also, if exist, the intercept term for the depreciation rate) that affect $\lambda$, and the $\beta$ s are the coefficients of each variable $Z_{i}$. Having established the basic model for domestic investment, the final models after combining the literature of past studies can be expressed as:

$$
D I N V_{t}=\alpha_{0}+\alpha_{1} G D P_{t}+\alpha_{2} D F D_{t}+\alpha_{3} I F D I_{t}+\alpha_{4} O F D I_{t}+\varepsilon_{t}
$$


where $D I N V$ stands for domestic investment, $D F D$ represents domestic financial development, IFDI denotes inflows of FDI into Indonesia and $O F D I$ represents outward of FDI from Indonesia. DINV is represented by domestic gross fixed capital investment as percentage of GDP, GDP is proxied by log of real GDP, DFD is represented by domestic credit to private sector as percentage of GDP,,$^{12}$ IFDI is proxied by net inflows of FDI as percentage of GDP, and $O F D I$ is proxied by outward of FDI from Indonesia as percentage of GDP. All data are collected from World Development Indicators (World Bank, 2019) with the exception for OFDI, which is gathered from UNCTADstat (UNCTAD, 2019). This study utilises data spanning from 1980 to 2018.

\section{Estimation Procedure: VECM}

Although the main objective of this study is to examine the implication of OFDI on economic growth of Indonesia, we are also interested to know the dynamic relationship between the two. Therefore, Granger causality test by Granger (1988), which is based on vector autoregression (VAR) will be applied. Nevertheless, for a time series analysis, to avoid spurious regression, the choice of VAR depends on the stationary condition of each variable. In the event that each variable is found to be non-stationary at level, vector error correction model (VECM) is preferred than the VAR model. ${ }^{13}$ VAR model could be considered mis-specified in the presence of variable(s) needs to be first difference, while to take first difference and run the equation in difference equation result in the loss of long-run information, which contained in equation at level. VECM is then considered the most preferred approach as it can incorporate short-run dynamic with long-run equilibrium (Kim, 1998). Therefore, the first test that we need to perform is unit root or stationarity test. Two most common tests, namely the Phillips-Perron (PP) (Phillips \& Perron, 1988) and augmented Dickey-Fuller (ADF) (Dickey \& Fuller, 1981) will be employed to confirm the existence of unit root problem. The ADF test is based on $\Delta Y_{t}=\alpha_{0}+\alpha_{1} t+\alpha_{2} Y_{t-1}+\sum_{i=1}^{\rho} \beta_{i} \Delta Y_{t-1}+\varepsilon_{t}$, where the null hypothesis refers to HO: $\alpha_{2}=0$ against the alternative hypothesis of $\mathrm{Ha}: \alpha_{2} \neq 0$. Phillips and Perron's test statistics can be viewed as Dickey-Fuller statistics that have been made robust to serial correlation by using the Newey and West (1987) heteroskedasticity- and autocorrelation-consistent covariance matrix estimator. One important step is to choose the optimum lag length. To assist us, we opt for the Schwarz Bayesian Criterion (SBC) (Schwartz, 1978). 
Table 1

Unit root tests

\begin{tabular}{lcccccccc}
\hline & \multicolumn{4}{c}{ PP test } & \multicolumn{3}{c}{ ADF test } \\
\hline & \multicolumn{2}{c}{ Level } & \multicolumn{2}{c}{ 1st difference } & \multicolumn{2}{c}{ Level } & \multicolumn{2}{c}{ 1st difference } \\
\hline DINV & -1.500 & -1.705 & $-4.435^{* * *}$ & $-4.372^{* * *}$ & -1.715 & -1.938 & $-4.424^{* * *}$ & $-4.360^{* * *}$ \\
lnGDP & 0.164 & -1.953 & $-4.656^{* * *}$ & $-4.636^{* * *}$ & 0.165 & -2.272 & $-4.662^{* * *}$ & $-4.640^{* * *}$ \\
DFD & -1.869 & -1.212 & $-9.057^{* * *}$ & $-9.632^{* * *}$ & -1.869 & -2.196 & $-5.936^{* * *}$ & $-5.860^{* * *}$ \\
IFDI & -2.060 & -1.805 & $-4.363^{* * *}$ & $-4.341^{* * *}$ & -2.383 & -2.296 & $-4.433^{* * *}$ & $-4.416^{* * *}$ \\
OFDI & -2.913 & -2.899 & $-9.256^{* * *}$ & $-9.532^{* * *}$ & -2.89 & -2.890 & $-9.087^{* * *}$ & $-9.005^{* * *}$ \\
\hline
\end{tabular}

Note: $\mathrm{C}$ refers to constant without trend and $\mathrm{C} \& \mathrm{~T}$ denotes constant with trend; DINV refers to domestic investment; ${ }^{* * *}$ denotes significant at $1 \%$; $\ln$ GDP refers to log of real GDP; DFD denotes domestic financial development; IFDI stands for inward FDI and OFDI represents outward FDI

From Table 1, all variables are not stationary at level, but turn to be stationary after first difference. Hence, we can conclude that all variables are integrated at order of 1 , or $I(1)$. Given the non-stationary nature of all variables, standard estimation procedure of ordinary least square will offer bias in the results. As the alternative, error correction model has been developed and introduced. As stated by Engel and Granger (1987) that if two (or more) variables are individually integrated of order one, and they are collectively cointegrated, then a causal relationship between (among) the variables could exist at least in one direction. To test for the existence of cointegration, we utilise two tests, namely the trace statistics and the maximum eigenvalue statistics (Johansen \& Juselius, 1990). Both tests can be expressed as follows:

$$
\lambda_{\text {trace }}=-T \sum_{i=r+1}^{n} \log \left(1-\hat{\lambda}_{1}\right)
$$

where $\lambda_{r+1}, \ldots, \lambda_{p}$ are the $p-r$ smallest squared canonical correlation.

$$
\lambda_{\max }=-T \log \left(1-\hat{\lambda}_{r+1}\right)
$$

where $\lambda_{r+1}$ refers to the $(r+t)^{t h}$ largest squared canonical correlation. 
Tutik Wiryanti Gondo et al.

Table 2

Lag length selection

\begin{tabular}{lcccccc}
\hline Lag & LogL & LR & FPE & AIC & SC & HQ \\
\hline 1 & -615.278 & NA & $4.83 \mathrm{e}+09$ & 36.486 & 36.711 & 36.563 \\
2 & -431.673 & 302.408 & 436488.2 & 27.157 & $28.504^{*}$ & 27.616 \\
3 & -400.935 & $41.586^{*}$ & 344852.2 & 26.819 & 29.288 & 27.661 \\
4 & -380.501 & 21.636 & 597958.6 & 27.088 & 30.679 & 28.313 \\
5 & -279.505 & 30.426 & $225623.6^{*}$ & $24.088^{*}$ & 29.924 & $26.078^{*}$ \\
\hline
\end{tabular}

Note: $\log \mathrm{L}$ is $\log$ likelihood; LR stands for sequential modified LR test statistic (each test at $5 \%$ level); FPE is final prediction error; AIC denotes Akaike information criterion; SC is Schwarz information criterion; HQ represents Hannan-Quinn information criterion; ${ }^{*}$ denotes the suggested lag length by each criterion

Prior to the tests, we need to choose the optimal lag length for the VECM. Table 2 tabulates the results suggested by several tests. Similar to unit root test, for VECM, we also rely on Schwarz criterion as the test has tendency to suggest shorter lag and suitable to out short sample. As shown in Table 3, both tests suggest that all variables are cointegrated at order of 1 at $5 \%$ critical value. In other words, there is one co-integrating relationship among the variable and therefore, the variables are said as having co-movement in the long run.

Table 3

Cointegration test

\begin{tabular}{lccc}
\hline $\mathrm{H} 0$ & $\lambda_{\text {trace }}$ & $5 \%$ Critical value & $p$-value \\
\hline $\mathrm{r}=0$ & 74.8482 & 69.8188 & $0.0187^{* *}$ \\
$\mathrm{r} \leq 1$ & 47.8118 & 47.8561 & 0.1505 \\
$\mathrm{r} \leq 2$ & 26.4674 & 29.7970 & 0.1153 \\
$\mathrm{r} \leq 3$ & 8.4685 & 15.4947 & 0.4167 \\
$\mathrm{r} \leq 4$ & 3.0802 & 3.8414 & 0.0792 \\
& $\lambda_{\max }$ & & \\
$\mathrm{r}=0$ & 38.0364 & 33.8768 & $0.0414^{* *}$ \\
$\mathrm{r}=1$ & 21.3443 & 27.5843 & 0.2560 \\
$\mathrm{r}=2$ & 17.9989 & 21.1316 & 0.1299 \\
$\mathrm{r}=3$ & 5.3882 & 14.2646 & 0.6922 \\
$\mathrm{r}=4$ & 3.0802 & 3.8414 & 0.0792 \\
\hline
\end{tabular}

Note: $\lambda_{\max }$ refers to maximum eigenvalue; ${ }^{* *}$ denotes significant at $5 \%$ 
Once we have confirmed that there is a co-integration among the variables, we can now examine the long-run relationship, which is embedded in the error correction model (ECM). In ECM form, Equation 9 can be expressed as:

$$
\begin{aligned}
\Delta D I N V_{t}= & \varphi_{0}+\sum_{i=1}^{n} \varphi_{1 i} \Delta \ln G D P_{t-1}+\sum_{i=1}^{n} \varphi_{2_{i}} \Delta D F D_{t-i}+ \\
& \sum_{i=1}^{n} \varphi_{3 i} \Delta I F D I_{t-1}+\sum_{i=1}^{n} \varphi_{5 i} \Delta O F D I_{t-1}+\varphi_{6} E C T_{t-1}+\zeta_{t}
\end{aligned}
$$

where ECT stands for error correction term, $n$ is the maximum lag length, and $\Delta$ denotes for first difference. GDP enters in natural log form, but no notation is added to conserve space. If long-run relationship exists, then ECT should be significant with negative sign. To form vector, the other equations can be expressed as:

$$
\begin{aligned}
& \Delta \ln G D P_{t}=\gamma_{0}+\sum_{i=1}^{n} \gamma_{1 i} \Delta \ln G D P_{t^{-1}}+\sum_{i=1}^{n} \gamma_{2 i} \Delta D F D_{t-i}+\sum_{i=1}^{n} \gamma_{3 i} \Delta I F D I_{t^{-i}}+ \\
& \sum_{i=1}^{n} \gamma_{4 i} \Delta O F D I_{t-i}+\gamma_{6} E C T_{t-1}+\zeta_{t} \\
& \Delta D F D_{t}=\theta_{0}+\sum_{i=1}^{n} \theta_{1 i} \Delta \ln G D P_{t-1}+\sum_{i=1}^{n} \theta_{2 i} \Delta D F D_{t-i}+\sum_{i=1}^{n} \theta_{3 i} \Delta I F D I_{t-i}+ \\
& \sum_{i=1}^{n} \theta_{4 i} \Delta O F D I_{t-i}+\theta_{6} E C T_{t-1}+\zeta_{t} \\
& \Delta I F D I_{t}=\delta_{0}+\sum_{i=1}^{n} \delta_{1 i} \Delta \ln G D P_{t^{-1}}+\sum_{i=1}^{n} \delta_{2 i} \Delta D F D_{t^{-i}}+\sum_{i=1}^{n} \delta_{3 i} \Delta I F D I_{t^{-i}}+ \\
& \sum_{i=1}^{n} \delta_{4 i} \Delta O F D I_{t-i}+\delta_{6} E C T_{t-1}+\zeta_{t} \\
& \Delta O F D I_{t}=\phi_{0}+\sum_{i=1}^{n} \phi_{1 i} \Delta \ln G D P_{t-1}+\sum_{i=1}^{n} \phi_{2 i} \Delta D F D_{t-i}+\sum_{i=1}^{n} \phi_{3 i} \Delta I F D I_{t-i}+ \\
& \sum_{i=1}^{n} \phi_{4 i} \Delta O F D I_{t-i}+\phi_{6} E C T_{t-1}+\zeta_{t}
\end{aligned}
$$

Finally, as argued by Engel and Granger (1987), if individually two variables are integrated at order of one, and they are also co-integrated collectively, then, there may be a causal relationship, at least in one direction. Granger causality will be conducted to check the dynamic relationship among the variables. To complement causality test, this study will also show the results of impulse response function (IRF). 


\section{RESULTS}

We begin the discussion on results by summarising the statistics of each variable as shown in Table 4. The low standard deviation for GDP and OFDI may suggest that there is limited growth in both variables. The slow growth of OFDI could be desirable in Indonesia, given the limited domestic capital but for GDP, it could be completely undesirable considering that Indonesia was an "Asian Tiger" alongside Malaysia and Thailand under second tier newly industrialising countries prior to the 1997 Asian economic crisis. What also surprising is the low standard deviation for IFDI into Indonesia, which means that Indonesia is unlikely to be very successful in attracting FDI over time. With relatively similar information between IFDI into and OFDI from Indonesia with slightly higher for IFDI, we are unsure if Indonesia can tolerate any outflow of capital. As the most badly affected country by the 1997 economic crisis, which followed by significant drop in FDI inflows and drop in domestic investment due to low firms' performance, it is evident that Indonesia is still heavily reliant on FDI inflows and sustained increment in domestic investment for its economic development.

Table 4

Descriptive analysis

\begin{tabular}{lrrrrrr}
\hline & Mean & Median & Max & Min & SD & Obs \\
\hline DINV & 26.633 & 26.992 & 32.812 & 19.429 & 4.377 & 39 \\
lnGDP & 26.852 & 26.876 & 27.768 & 25.925 & 0.536 & 39 \\
DFD & 32.412 & 27.658 & 60.849 & 9.680 & 13.692 & 39 \\
IFDI & 0.881 & 0.849 & 2.739 & -2.583 & 1.149 & 39 \\
OFDI & 0.370 & 0.260 & 1.587 & -1.310 & 0.504 & 39 \\
\hline
\end{tabular}

Note: SD stands for standard deviation; Obs refers to observation; all variables are as percentage of GDP, except for $\operatorname{lnGDP}$

From the simple correlation as shown in Table 5, we can observe that all factors are generally contributing positively to domestic investment (DINV), with GDP has the highest possible contribution to improvement in domestic investment. It is easily understood by the fact that GDP is also representing firms' production growth, which later reinvested. Positive correlation between OFDI and IFDI is also expected. However, what not known is the reasoning behind this positive comovement. It can be in the negative perspective that FDI inflows crowd out local firms to search for new business location abroad. It can be due to positive integration of the two in the sense that FDI inflows help strengthening domestic firms, to the extent that they are able to invest abroad. Overall, there is no high correlation among the variables, implying that there is no serious issue of multicollinearity in the model. 
Table 5

Correlation analysis

\begin{tabular}{lccccc}
\hline & DINV & $\operatorname{lnGDP}$ & DFD & IFDI & OFDI \\
\hline DINV & 1.000 & & & & \\
lnGDP & 0.610 & 1.000 & & & \\
DFD & 0.570 & 0.190 & 1.000 & & \\
IFDI & 0.600 & 0.320 & -0.040 & 1.000 & \\
OFDI & 0.000 & 0.340 & 0.110 & 0.040 & 1.000 \\
\hline
\end{tabular}

Having confirmed that all variables are stationary at first difference (see Table 1) and all variables are co-integrated at order 1 (see Table 3), Table 6 highlights the results of the long-run and short-run equations. Focusing on the short-run regression results, the error correction term (ECT) has been found to be significant at $10 \%$ and negative. ECT confirms the existence of long-run relationship among the variables, complementing the co-integration results. Prior to ECT, the overall model of error correction also passed all diagnostic tests, namely serial correlation, heteroscedasticity, and stability. The model, which embeds the long-run equation is therefore considered as reliable. Regarding the significantly positive role of GDP is obvious; higher GDP means more profit or income, which later will be reinvested or deposited and ready for prospective investments. Conversely, higher GDP also indicates better economic opportunities to be tap by investors, either local or foreign. Impressive GDP may function as a hint and indicate profitability level that can attract more investment in the future. Very often at the back of desirable GDP, conducive support system such as good governance and infrastructure is also well installed (Kolstad and Villanger, 2004).

Table 6

Long-run and short-run equations

\begin{tabular}{|c|c|c|c|}
\hline \multicolumn{4}{|c|}{$\begin{aligned} \mathrm{DINV}= & 8.0670 \operatorname{lnGDP}+0.1505 \mathrm{DFD}-1.2171 \mathrm{IFDI}-0.7625 \mathrm{OFDI}-30.1193 \\
& {[1.9356]^{*} \quad[2.5709]^{* *} \quad[-1.0128] \quad[-5.9406]^{* *} } \\
\text { The corresponding error correction model: } & \\
\Delta \mathrm{DINV}= & -0.158 \mathrm{ECT}(-1)^{*}+0.0511 \Delta \mathrm{DINV}(-1)^{* *}-0.0336 \Delta \mathrm{DINV}(-2)+9.0445 \Delta \ln \mathrm{GDP}(-1) \\
& +9.2559 \Delta \operatorname{lnGDP}(-2)^{*}-0.1623 \Delta \mathrm{DFD}(-1)^{* *}-0.0194 \Delta \mathrm{DFD}(-2)-0.0446 \Delta \mathrm{IFDI}(-1)- \\
& 0.0019 \Delta \mathrm{IFDI}(-2)+1.0327 \Delta \mathrm{OFDI}(-1)^{*}+0.9208 \Delta \mathrm{OFDI}(-2)-0.9525\end{aligned}$} \\
\hline Adjusted-R ${ }^{2}$ & 0.558 & Heteroscedasticity & 0.364 \\
\hline Serial correlation & 0.618 & Stability & 0.178 \\
\hline
\end{tabular}

Note: ${ }^{*},{ }^{* *}$, and ${ }^{* * *}$ denote significant at $10 \%, 5 \%$, and $1 \%$ critical values, respectively; figures in [ ] stand for $t$-statistics; LM test is used to check serial correlation; ARCH test is applied to confirm the heteroscedasticity problem; Ramsey reset test is applied to check the model stability; the figures for serial correlation, heteroscedasticity, and stability refer to $p$-value 
The effect of domestic financial development on domestic investment is also significantly positive, in line with several other studies such as Ndikumana (2000) and Dutta and Roy (2009).

This can be explained by the fact that banks can enhance domestic investment in various ways. First, by pooling savings, banks can rise size of funds available for investment. By exploiting economies of scale in information gathering and processing, financial intermediaries can optimise the collection costs of savings from various types of saving units (Ndikumana, 2005). Second, banks can help reducing liquidity risk and subsequently, enhancing domestic investment (Diamond \& Dybvig, 1983; Bencivenga \& Smith, 1991; Ndikumana, 2005). One crucial attribute of investment is regarding its large capital commitment over relatively long period. Without bank services, individual may suffer serious issue on firm's liquidity in their asset portfolios and has to weigh serious the intention to undertake any form of investment due to lack of capital. Third, given its ability to gather huge information about various investments, financial intermediaries play a vital role in lowering the costs of information of prospective investment activities (Diamond, 1984). Banks will then play the role of delegated monitors of investment companies on behalf of the individual investors. A developed financial system, therefore, should encourage more investment and more efficient capital allocation (Ndikumana, 2005). Moreover, with the latest development in Islamic finance, Indonesia has more means to promote domestic investment and expected to increase the level of financial inclusion and financial deepening. This reflected the current trend of Islamic financial services in Indonesia, which encompasses 10 Islamic commercial banks, with 111 branches, 23 Islamic windows with 251 branches across Indonesia, as well as 149 Shariah community finance banks (Abduh \& Omar, 2012; Puteh et al., 2018). All in all, the latest progression in overall financial structure of Indonesia, we can expect to see smooth growth of domestic investment.

Surprisingly, the inflows of FDI into Indonesia exert a negative and significant impact on domestic investment. Although it is against the theoretical norm that FDI will strengthen domestic investment, looking at the pattern of FDI inflows shown in Figure 2, it is understood why the result is negative. Uncertainty in FDI inflows and only recently recorded positive or recovery trend could be the explanations. As explained by Lindblad (2015), since the 1997 economic crisis, and despite rich in natural resources and abundant cheap labour supply, Indonesia has not been so successful in attracting FDI. Lipsey and Sjöholm (2011) concur with the statement by Lindblad (2015) that FDI inflows into Indonesia can be considered as outlier within the northeast and southeast Asian region, even in the core area such as manufacturing. Khaliq and Noy (2007) also share another insight 
about the issue that FDI into some sectors such as mining and quarrying which has been recorded as negative contribution. Although FDI in some other sectors shows a positive effect, certainly the positive effect has been fully offset by the negative contribution, leaving a minimum role of FDI in Indonesia. Similarly, we can use similar argument that the negative effect of FDI could probably reduce the domestic investment in Indonesian mining and quarrying sectors, lowering the potential huge domestic investment creation by FDI inflows.

Finally, on the effect of OFDI, the negative effect is as expected. Although the third wave of OFDI maintains the typical motivations, ${ }^{14}$ namely marketseeking, efficiency-seeking, and assets-seeking, according to Rasiah et al. (2010), technology-seeking has been dominating the motive of OFDI during the third wave. Nevertheless, Indonesian OFDI is most likely to be under the second wave, from perspectives of period, motive of outflow as well as the latest attribute of the third wave of OFDI. Surprisingly, if we strictly examine, it is also hard to say that Indonesian transnational corporations (TNCs) are within the second wave although it happens to start in 1980s. This could be due to the non-emergence of any Indonesian TNC to be the giant company todays and capable to compete with other TNCs from other Asian countries such as Hyundai from South Korea and Sime Darby from Malaysia. In other word, with limited expansion can be seen from Indonesian TNCs, they might not be able to follow the conditions mentioned above about how OFDI may not be reducing domestic investment. Hence, the negative result is justified. China has been successfully integrated OFDI with domestic investment and Indonesia should learn from China. According to Gondim et al. (2018), among the key strengths of China's OFDI that bring positive effect on domestic investment are: (1) prioritising on resource-seeking OFDI with primary target to acquire scarce raw materials and energy, ${ }^{15}(2)$ continued policy to support OFDI as part of the strategies to integrate China to global economy, ${ }^{16}$ and (3) related to item number 2, China has created approximately 130 bilateral investment treaties to protect China's OFDI. Unlike China, one of the reasons that Brazilian OFDI has no effect on domestic investment is that no bilateral investment treaty to safeguard its OFDI. 
Tutik Wiryanti Gondo et al.

Table 7

Granger causality ${ }^{17}$

\begin{tabular}{lcccccc}
\hline & $\Delta$ DINV & $\Delta \operatorname{lnGDP}$ & $\Delta$ DFD & $\Delta$ IFDI & $\Delta$ OFDI & ECT $(-1)$ \\
\hline \multicolumn{7}{c}{$\chi^{2}$-statistic } \\
$\Delta \ln$ GDP & - & 4.021 & 4.382 & 2.238 & 0.285 & $-0.158[-1.963]^{*}$ \\
$\Delta$ DFD & $8.215^{* *}$ & - & 1.263 & $46.289^{* * *}$ & $10.815^{* * *}$ & $-0.001[-1.477]$ \\
$\Delta$ IFDI & $4.655^{*}$ & 2.626 & - & 1.016 & 2.923 & $0.186[2.681]^{* * *}$ \\
$\Delta$ OFDI & 0.374 & 0.453 & 1.429 & - & 4.114 & $-0.114[-0.179]$ \\
\hline
\end{tabular}

Note: ${ }^{*},{ }^{* *}$, and ${ }^{* * *}$ denote significant at $10 \%, 5 \%$, and $1 \%$ critical values, respectively; figures in [ ] stand for $t$-value
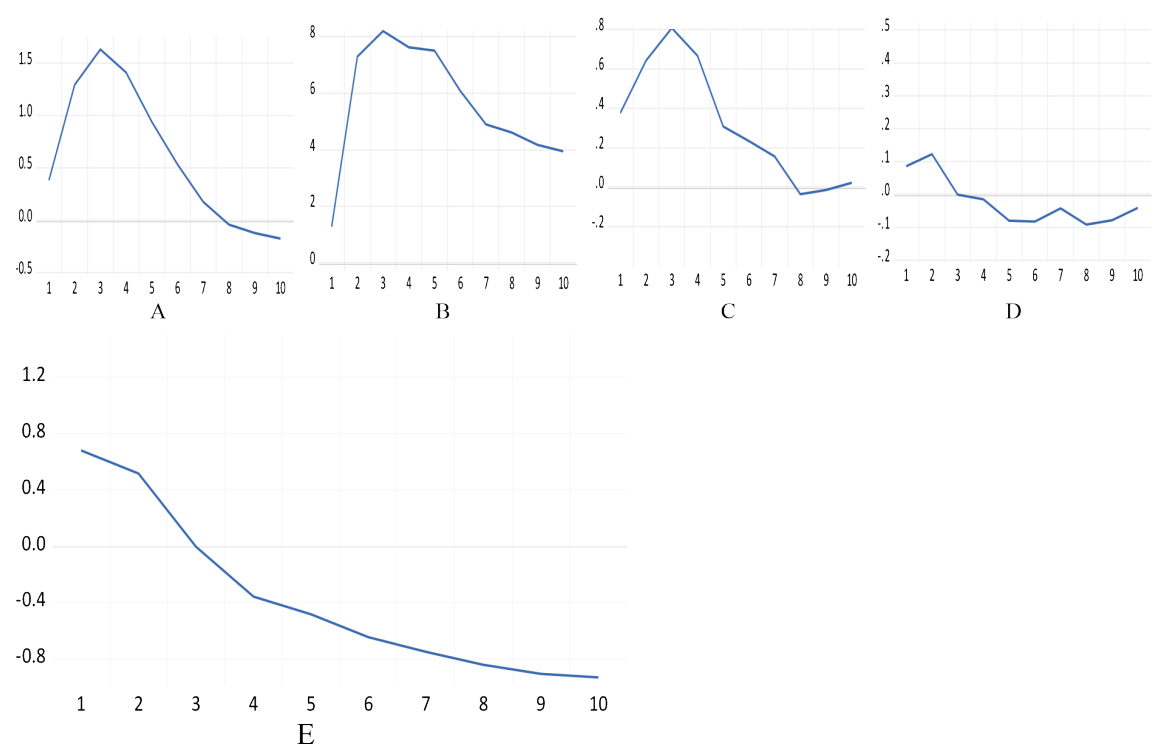

Figure 3. (a) DINV on GDP, (b) DFD on GDP, (c) IFDI on GDP, (d) OFDI on GDP, and (e) OFDI on GDP

With a negative effect of OFDI on domestic investment, in the next analyses, we try to investigate whether OFDI can still positively affect domestic investment if the conditions stipulated in the literature section are met. The conditions are: (1) domestic financial development is sufficiently high enough to compensate for outflow of FDI from Indonesia, (2) inflows of FDI into Indonesia is also significantly high to off-set the outflow of FDI from Indonesia, and (3) OFDI from Indonesia will invite more demand for exports, leading to domestic firms' expansion in respond. 
Table 8

Long- and short-run equations with marginal effect analysis [DV: DINV]

\begin{tabular}{|c|c|c|}
\hline & Condition: IFDI ${ }^{\mathrm{a}}$ & Condition: $\mathrm{DFD}^{\mathrm{b}}$ \\
\hline $\operatorname{lnGDP}$ & $8.1944[5.4947]^{* * *}$ & $7.78806[2.3919]^{* *}$ \\
\hline DFD & $0.3034[6.9727]^{* * *}$ & $0.5042[2.5732]^{* * *}$ \\
\hline IFDI & $4.6833[11.7874]^{* * *}$ & $1.9712[4.8644]^{* * *}$ \\
\hline OFDI & $-2.7625[-6.7881]^{* * *}$ & $-2.5882[-2.3563]^{* * *}$ \\
\hline OFDI*IFDI & $5.8937[9.8763]^{* * *}$ & - \\
\hline \multirow[t]{2}{*}{ OFDI*DFD } & - & $1.0671[2.7168]^{* * *}$ \\
\hline & \multicolumn{2}{|c|}{ Model criterion } \\
\hline Adjusted-R ${ }^{2}$ & 0.4101 & 0.3736 \\
\hline Serial correlation & 0.235 & 0.234 \\
\hline Heteroscedasticity & 0.641 & 0.548 \\
\hline \multirow[t]{2}{*}{ Normality } & 0.214 & 0.229 \\
\hline & \multicolumn{2}{|c|}{ Marginal effect } \\
\hline At mean & 2.4298 & -1.6480 \\
\hline At $\min$ & -17.9859 & -5.3445 \\
\hline \multirow[t]{2}{*}{ At $\max$} & 13.3803 & 0.3346 \\
\hline & \multicolumn{2}{|c|}{ Error correction model } \\
\hline \multicolumn{3}{|c|}{$\begin{aligned} \mathrm{a} \Delta \mathrm{DINV}= & -0.1223 \mathrm{ECT}(-1)^{*}+0.1569 \Delta \mathrm{DINV}(-1)-0.0935 \Delta \mathrm{DINV}(-2)+26.0881 \Delta \operatorname{lnGDP}(-1)^{*} \\
& +7.1979 \Delta \operatorname{lnGDP}(-2)-0.0003 \Delta \mathrm{DFD}(-1)-0.0119 \Delta \mathrm{DFD}(-2)-1.2019 \Delta \mathrm{IFDI}(-1)- \\
& 1.1510 \Delta \mathrm{IFDI}(-2)-1.2766 \Delta \mathrm{OFDI}(-1)-0.1816 \Delta \mathrm{OFDI}(-2)+1.9959 \Delta(\mathrm{OFDI} \\
& \left.(-1)^{*} \mathrm{IFDI}(-1)\right)+1.2203 \Delta\left(\mathrm{OFDI}(-2)^{*} \operatorname{IFDI}(-2)\right)-0.7413 . \\
& +0.0452 \mathrm{ECT}(-1)^{*}+0.2398 \Delta \mathrm{DINV}(-1)-0.0550 \Delta \mathrm{DINV}\left(-2+24.6540 \Delta \operatorname{lnGDP}(-1)^{* *}\right. \\
& +10.9067 \Delta \ln \mathrm{DDP}(-2)-0.0595 \Delta \mathrm{DFD}(-1)+0.0510 \Delta \mathrm{DFD}(-2)-0.0626 \Delta \mathrm{IFDI}(-1)+ \\
& 0.0950 \Delta \mathrm{IFDI}(-2)+3.7942 \Delta \mathrm{OFDI}(-1)-2.6959 \Delta \mathrm{OFDI}(-2)-0.0882 \Delta(\mathrm{OFDI} \\
& \left.(-1)^{*} \mathrm{DFD}(-1)\right)+0.0678 \Delta\left(\mathrm{OFDI}(-2)^{*} \mathrm{DFD}(-2)\right)-0.9277 .\end{aligned}$} \\
\hline
\end{tabular}

Note: ${ }^{*},{ }^{* *}$, and ${ }^{* * *}$ denote significant at $10 \%, 5 \%$, and $1 \%$, respectively; figure in [ ] stands for $t$-statistic and in ( ) stands for time lag

Unfortunately, while we are interested at the third condition, model specification requires the two more additional variables, namely exports and interaction term between OFDI and exports. The accurate model suffers lower degree of freedom, given limited sample size of this study. Moreover, we have difficult time to identify the appropriate measure of exports to really represent feedback demand due to overseas operation of TNCs. Hence, this issue we leave to future research. With two conditions remain, based on Table 8 , this study confirms the significant conditions offered by high inflows of FDI and high development of domestic financial system. IFDI relatively more powerful than DFD as at mean, it can help 
OFDI to generate positive effect on domestic investment as shown in marginal effect column. The negative marginal effect when DFD is at mean also highlight the insufficient development of Indonesian financial system to support aggressive economic activities.

\section{CONCLUSION}

Indonesia has joined the group of second wave of OFDI from Asian countries. Nevertheless, with the failure of luring similar amount of IFDI after the 1997 Asian economic crisis, OFDI from Indonesia may jeopardise Indonesian economic development by reducing domestic investment. Since no past study deals with this issue, this study could be among the first to investigate the issue. Applying VECM for data spanning from 1980 until 2018, we confirm our intuition that OFDI may dampen domestic investment.

As part of the possible suggestions is for Indonesian government to implicitly as well as explicitly discourage OFDI by giving more incentives, rather than penalties. More incentives and attraction must also be created to ensure that more IFDI will come to Indonesia given the current small number of inflows relative to other neighbouring Asian countries. By doing so, Indonesian government is no longer has to worry about OFDI as sufficiently high IFDI may fully compensate for OFDI to maintain or even spur higher domestic investment. Indonesian government can also think of enhancing the already fast-growing economic segments to be more developed and friendly to the local entrepreneurs so that they can actively involve in doing domestic investment activities.

\section{NOTES}

1. FDI can take several forms such as greenfield investment, mergers and acquisitions, and joint venture.

2. The positive effects of FDI on economic development in host countries, either developed or developing countries are through the channels such as the transfer of know-how, the accrual of investment funds, and even the improvement of labour standards (Farla et al., 2016).

3. Domestic investment is not necessarily by local investors only. It is the sum of both, local and foreign investors' investment.

4. We just refer to the volume of inflows, and not really on its connection with GDP. In other word, even though IFDI could be helpful to Indonesian economic growth, its contribution relative to other growth factors' contribution could be at minimum. Continuous reform of institutional quality as well as investment incentives have been among the attraction to MNCs to invest in Indonesia (OECD, 2010). Nevertheless, 
Masron (2017), Masron and Naseem (2017), and Masron et al. (2018) argue that improvement in institutional quality is purely a necessary condition but not a sufficient condition to lure MNCs. We suspect the same thing goes to Indonesia.

5. Neverheless, Green (1997) also reminds about the potential over investment due to too many incentives by government. The argument is that current tax policy to re-channel domestic investment to be more into housing has led to over-investment.

6. According to Felstein and Horioka (1980), the reason is that saving in each country is looking for worldwide profitable investment opportunities, while investment in each country is the amount of financing given by pool of capital available worldwide. This is contrary to the general believe that high GDP will bring more saving as in most of the time, people will associate this to the example of Japan.

7. Among countries which are relying highly on bank-based financial system are Germany and Japan. The United States and England are particularly emphasising on stock-market based system (Ndikumana, 2005).

8. Stock-market based system also offers several advantages. First, stock market may induce more investment because it can identify the fundable projects, which can offer good return. Or else, stock market (i.e., stock price) may indicate that the project should not be undertaken. Second, by virtue of risk sharing among the stockholders, stock market can expand its liquidity and decrease the cost of equity capital. Third, stock market signal to the public about the performance of publicly listed firms and therefore, put pressure on firms' top management to perform. High profitability will encourage firms and individual stockholders to put more investment and hence, more domestic investment (Ndikumana, 2005).

9. $\mathrm{Xu}(2000)$ and Choong (2012), on the other hand, argue that financial development will promote economic growth through domestic investment channel. Indirectly, these studies conclude that financial development will promote domestic investment, from which economic growth will be stimulated.

10. In addition, Javorcik et al. (2004) stress on the shared ownership as the mean to create win-win outcome. The key argument is that foreign know-how can really be jointly utilised by domestic firms to enhance their efficiency and profitability.

11. This also means that if MNCs can venture into new business area, which is yet to be explored by local firms, then the effect will be multifold.

12. We did try to apply domestic credit by financial services as percentage of GDP, but the results remain the same. We do not report to conserve space but available upon request.

13. Regardless of VAR or VECM, among the benefits of applying them are: (i) all variables are assumed to be endogenous and therefore, prior assumption about causality is not really needed, and (ii) dynamic causality among the variables can be investigated, which can allow for more insight among the relationship.

14. The first wave refers to OFDI with market-seeking and efficiency-seeking motives, mainly driven by TNCs from Latin America from the 1960s until early 1980s. The second wave in the 1980s represented by the previous combined motivations as well as the newly emerged motivation, which is strategic asset seeking motive. The second wave is dominated by Asian TNCs, mainly from South Korea, Hong Kong, and 
Taiwan. The third wave originated in 1990s in which large Asian TNCs are competing with TNCs from developed countries.

15. Also, strategic assets in semiconductors and other advanced sectors (Gondim et al., 2018). This is to ensure technological catch-up.

16. You and Solomon (2015) also highlight the importance role by China's government in supporting domestic investment, which later translated into OFDI. In other words, China's OFDI is mostly due to their internal strength.

17. The full set of vector error correction model (VECM) is available in the Appendix.

\section{REFERENCES}

Abduh, M., \& Omar, M. A. (2012). Islamic banking and economic growth: The Indonesian experience. International Journal of Islamic and Middle Eastern Finance and Management, 5(1), 35-47. https://doi.org/10.1108/17538391211216811

Alguacil, M., Cuadros, A., \& Orts, V. (2004). Does saving really matter for growth? Mexico (1970-2000). Journal of International Development, 16(2), 281-290. https://doi.org/10.1002/jid.1075

Alguacil, M., Cuadros, A., \& Orts, V. (2011). Inward FDI and growth: The role of macroeconomic and institutional environment. Journal of Policy Modeling, 33(3), 481-496. https://doi.org/10.1016/j.jpolmod.2010.12.004

Ameer, W., Xu, H., \& Alotaish, M. S. M. (2017) Outward foreign direct investment and domestic investment: Evidence from China. Economic Research/Ekonomska Istraživanja, 30(1), 777-788. https://doi.org/10.1080/1331677X.2017.1314824

Ang, J. B. (2007). Are saving and investment cointegrated? The case of Malaysia (1965-2003). Applied Economics, 39(17), 2167-2174. https://doi. org/10.1080/00036840600722281

Apergis, N., Katrakilidis, C., \& Tabakiss N. M. (2006). Dynamic linkages between FDI inflows and domestic investment: A panel co-integration approach. Atlantic Economic Journal, 34, 385-394. https://doi.org/10.1007/s11293-006-9026-x

Balasubramanyam, V. N., Salisu, M., \& Sapsford, D. (1996). Foreign direct investment and growth in EP and IS countries. The Economic Journal, 106(434), 92-105. https://doi.org/10.2307/2234933

Barrell, R., \& Pain, N. (1997). Foreign direct investment, technological change, and economic growth within Europe. The Economic Journal, 107(445), 1770-1786. https://doi.org/10.1111/j.1468-0297.1997.tb00081.x

Bencivenga, V., \& Smith, B. (1991). Financial intermediation and endogenous growth. Review of Economic Studies, 58(2), 195-209. https://doi.org/10.2307/2297964

Borensztein, E., De Gregorio, J., \& Lee, J. W. (1998). How does foreign direct investment affect economic growth? Journal of International Economics, 45(1), 115-135. https://doi.org/10.1016/S0022-1996(97)00033-0

Boswell, T., \& Dixon, W. J. (1990). Dependency and rebellion: A cross-national analysis. American Sociological Review, 55(4), 540-559. https://doi.org/10.2307/2095806

Bosworth, B. P. (1993). Saving and investment in a global economy. Washington, DC: The Brookings Institution. 
Choong, C. K. (2012). Does domestic financial development enhance the linkages between foreign direct investment and economic growth? Empirical Economics, 42(3), 819-834. https://doi.org/10.1007/s00181-011-0455-2

Desai, M. A., Foley, C. F., \& Hines Jr, J. R. (2005). Foreign direct investment and the domestic capital stock. American Economic Review, 95(2), 33-38. https://doi. org/10.1257/000282805774670185

De Vita, G., \& Abbott, A. (2002). Are saving and investment cointegrated? An ARDL bounds testing approach. Economics Letters, 77(2), 293-299. https://doi. org/10.1016/S0165-1765(02)00139-8

Diamond, D., \& Dybvig, P. (1983). Bank runs, deposit insurance and liquidity. Journal of Political Economy, 91(3), 401-419. https://doi.org/10.1086/261155

Diamond, D. (1984). Financial intermediation and delegated monitoring. Review of Economic Studies, 51(3), 393-414. https://doi.org/10.2307/2297430

Dickey, D.A., \& Fuller, W.A. (1981). Likelihood ratio statistics for autoregressive time series with a unit root. Econometrica, 49, 1057-1072. https://doi.org/10.2307/1912517

Dutta, N., \& Roy, S. (2009). The impact of financial development on domestic investment: A quantile regression approach. In S. Marjit (Ed.), India macroeconomics annual (pp. 111-134). India: Sage Publications.

Engel, R. F., \& Granger, C. W. (1987). Co-integration and error correction representation, estimation and testing. Econometrica, 55(2), 251-276. https://doi. org/10.2307/1913236

Farla, K., De Crombrugghe, D., \& Verspagen, B. (2016). Institutions, foreign direct investment, and domestic investment: Crowding out or crowding in? World Development, 88(December), 1-9. https://doi.org/10.1016/j. worlddev.2014.04.008

Feldstein, M., \& Horioka, C. (1980). Domestic savings and international capital flows. Economic Journal, 90(358), 314-329. https://doi.org/10.2307/2231790

Feldstein, M. S. (1995). The effects of outbound foreign direct investment on the domestic capital stock. In M. Felstein, J. R. Hines, \& G. Hubbard (Eds.), The effects of taxation on multinational corporations (pp. 43-66). Chicago: University of Chicago Press. https://doi.org/10.3386/w4668

Firebaugh, G. (1992). Growth effects of foreign and domestic investment. American Journal of Sociology, 98, 105-130. https://doi.org/10.1086/229970

Freckleton, M., Wright, A., \& Craigwell, R. (2012). Economic growth, foreign direct investment and corruption in developed and developing countries. Journal of Economic Studies, 39(6), 639-652. https://doi.org/10.1108/01443581211274593

Fry, M. J. (1988). Money, interest, and banking in economic development. Baltimore: Johns Hopkins University Press.

Furqani, H., \& Mulyany, R. (2009). Islamic banking and economic growth: Empirical evidence from Malaysia. Journal of Economic Cooperation and Development, 30(2), 59-74.

Gondim, I., Ogasavara, M. H., \& Masiero, G. (2018). Effects of outward foreign direct investment on domestic investment: The cases of Brazil and China. Journal of International Development, 30(8), 1439-1454. https://doi.org/10.1002/jid.3368 
Granger, C. W. (1988). Some recent development in a concept of causality. Journal of Econometrics, 39(1-2), 199-211. https://doi.org/10.1016/0304-4076(88)90045-0

Green, R. K. (1997). Follow the leader: How changes in residential and non-residential investment predict changes in GDP. Real Estate Economics, 25(2), 253-270. https://doi.org/10.1111/1540-6229.00714

Hejazi, W., \& Pauly, P. (2003). Motivations for FDI and domestic capital formation. Journal of International Business Studies, 34(3), 282-289. https://doi.org/10.1057/ palgrave.jibs. 8400030

Herwartz, H., \& Xu, F. (2009). Panel data model comparison for empirical savinginvestment relations. Applied Economics Letters, 16(8), 803-807. https://doi. org/10.1080/13504850701221949

Herzer, D., \& Schrooten, M. (2007). Outward FDI and domestic investment. DIW discussion papers no. 679. Berlin: DIW.

Javorcik, B. S., Saggi, K., \& Spatareanu, M. (2004). Does it matter where you come from? Vertical spillovers from FDI and investor nationality. World Bank Policy Research Working Paper No. 3449.

Johansen, S., \& Juselius, K. (1990). Maximum likelihood estimation and inference on cointegration, with applications to the demand for money. Oxford Bulletin of Economics and Statistics, 52(2), 169-210. https://doi. org/10.1111/j.1468-0084.1990.mp52002003.x

Jude, C. (2019). Does FDI crowd out domestic investment in transition countries? Economics of Transition and Institutional Change, 27(1), 163-200. https://doi. org/10.1111/ecot.12184

Khaliq, A., \& Noy, I. (2007). Foreign direct investment and economic growth: Empirical evidence from sectoral data in Indonesia. Journal of Economic Literature, 45(1), 313-325.

Kim, K. H. (1998). US inflation and the dollar exchange rate: A vector error correction model. Applied Economics, 30(5), 613-619. https://doi.org/10.1080/000368498325606

Kim, D. D. K., \& Seo, J. S. (2003). Does FDI inflow crowd out domestic investment in Korea? Journal of Economic Studies, 30(6), 605-622. https://doi. org/10.1108/01443580310504462

Kolstad, I., \& Villanger, E. (2004). How does social development affect FDI and domestic investment? CMI Report \#R2004:2. Norway: Chr. Michelsen Institute. Retrieved January 2020 from https://open.cmi.no/cmi-xmlui/handle/11250/2436078.

Levine, R., \& Renelt, D. (1992). A sensitivity analysis of cross-country growth regressions. The American Economic Review, 82(4), 942-963.

Levine, R. (2002). Bank-based or market-based financial systems: Which is better? Journal of Financial Intermediation, 11(4), 398-428. https://doi.org/10.1006/ jfin.2002.0341

Lindblad, J. T. (2015). Foreign direct investment in Indonesia: Fifty years of discourse. Bulletin of Indonesian Economic Studies, 51(2), 217-237. https://doi.org/10.108 0/00074918.2015.1061913

Lipsey, R. E., \& Sjöholm, F. (2011). Foreign direct investment and growth in East Asia: Lessons for Indonesia. Bulletin of Indonesian Economic Studies, 47(1), 35-63. https://doi.org/10.1080/00074918.2011.556055 
London, B., \& Robinson, T. D. (1989). The effect of international dependence on income inequality and political violence. American Sociological Review, 54(2), 305-308. https://doi.org/10.2307/2095798

Masron, T. A. (2017). Relative institutional quality and FDI inflows in ASEAN countries. Journal of Economic Studies, 44(1), 115-137. https://doi.org/10.1108/JES-042015-0067

Masron, T. A., \& Naseem, N. A. M. (2017). Institutional quality and foreign direct investment in ASEAN. Institutions and Economies, 9(4), 5-30.

Masron, T. A., Naseem, N. A. M., \& Wahab, E. A. A. (2018). Institutional quality in attracting foreign direct investment to small countries. Malaysian Journal of Economic Studies, 55(2), 267-284. https://doi.org/10.22452/MJES.vol55no2.7

Mišun, J., \& Tomšk, V. (2002). Does foreign direct investment crowd in or crowd out domestic investment? Eastern European Economics, 40(2), 38-56. https://doi.or $\mathrm{g} / 10.1080 / 00128775.2002 .11041015$

Mileva, E. (2008). The impact of capital flows on domestic investment in transition economies. European Central Bank Working Papers No 871/ February 2008. Retrieved January 2020 from https:/www.ecb.europa.eu/pub/pdf/scpwps/ ecbwp871.pdf.

Miller, S. M. (1988). Are saving and investment co-integrated? Economics Letters, 27(1), 31-34. https://doi.org/10.1016/0165-1765(88)90215-7

Mutenyo, J., \& Asmah, E. (2010). Does foreign direct investment crowd-out domestic private investment in sub-Saharan Africa? African Finance Journal, 12(1), $27-52$.

Ndikumana, L. (2000). Financial determinants of domestic investment in sub-Saharan Africa: Evidence from panel data. World Development, 28(2), 381-400. https:// doi.org/10.1016/S0305-750X(99)00129-1

Ndikumana, L. (2005). Financial development, financial structure, and domestic investment: International evidence. Journal of International Money and Finance, 24(4), 651-673. https://doi.org/10.1016/j.jimonfin.2005.03.006

Newey, W. K., \& West, K. D. (1987). Hypothesis testing with efficient method of moments estimation. International Economic Review, 28(3), 777-787. https:// doi.org/10.2307/2526578

OECD (Organisation for Economic Co-operation and Development). (2010). OECD investment policy reviews: Indonesia 2010. Paris: OECD.

Phillips, P. C., \& Perron, P. (1988). Testing for a unit root in time series regression. Biometrika, 75(2), 335-346. https://doi.org/10.1093/biomet/75.2.335

Pilbeam, K., \& Oboleviciute, N. (2012). Does foreign direct investment crowd in or crowd out domestic investment? Evidence from the European Union. The Journal of Economic Asymmetries, 9(1), 89-104. https://doi.org/10.1016/j.jeca.2012.01.005

Puteh, A., Rasyidin, M., \& Mawaddah, N. (2018). Islamic banks in Indonesia: Analysis of efficiency. Proceedings of MICoMS 2017, Emerald Reach Proceedings Series (vol. 1, pp. 331-336). Bingley: Emerald Publishing Limited. https://doi. org/10.1108/978-1-78756-793-1-00062

Rasiah, R., Gammeloft, P., \& Jiang, Y. (2010). Home government policies for outward FDI from emerging economies: Lessons from Asia. International Journal of Emerging Markets, 5(3/4), 333-357. https://doi.org/10.1108/17468801011058415 
Romm, A. T. (2005). The relationship between saving and growth in South Africa: A time series analysis. South African Journal of Economics, 73(2), 171-189. https://doi. org/10.1111/j.1813-6982.2005.00012.x

Sauramo, P. (2008). Does outward foreign direct investment reduce domestic investment: Macro-evidence from Finland. Labour Institute for Economic Research Discussion Paper No. 239. Helsinki: Labor Institute for Economic Research.

Schwartz, G. (1978). Estimating the dimension of a model. Annal of Statistics, 11, $417-$ 431. https://doi.org/10.1214/aos/1176344136

Solow, R. M. (1956). A contribution to the theory of economic growth. Quarterly Journal of Economics, 70, 65-94. https://doi.org/10.2307/1884513

Stevens, G. V. G., \& Lipsey, R. E. (1992). Interactions between domestic and foreign investment. Journal of International Money and Finance, 11(1), 40-62. https:// doi.org/10.1016/0261-5606(92)90020-X

Tang, S., Selvanathan, E. A., \& Selvanathan, S. (2008). Foreign direct investment, domestic investment and economic growth in China: A time series analysis. World Economy, 31(10), 1292-1309. https://doi.org/10.1111/j.1467-9701.2008.01129.x

UNCTAD (United Nations Conference on Trade and Development). (2019). UNCTADstat. Retrieved October 2019 from https://unctadstat.unctad.org/EN.

Wimberley, D. W. (1991). Transnational corporate investment and food the third world: A cross-national analysis 1. Rural Sociology, 56(3), 406-431. https://doi. org/10.1111/j.1549-0831.1991.tb00441.x

World Bank. (2018). Global investment competitiveness report 2017/2018: Foreign investor perspectives and policy implications. Washington, D.C.: World Bank. https://doi.org/10.1596/978-1-4648-1175-3

World Bank. (2019). World development indicators. Retrieved October 2019 from https:// databank.worldbank.org/source/world-development-indicators.

Yao, S., \& Wei, K. (2007). Economic growth in the presence of FDI: The perspective of newly industrialising economies. Journal of Comparative Economics, 35(1), 211-234. https://doi.org/10.1016/j.jce.2006.10.007

You, K., \& Solomon, O. H. (2015). China's outward foreign direct investment and domestic investment: An industrial level analysis. China Economic Review, 34(July), 249260. https://doi.org/10.1016/j.chieco.2015.02.006

$\mathrm{Xu}, \mathrm{Z}$. (2000). Financial development, investment, and economic growth. Economic Inquiry, 38(2), 331-344. https://doi.org/10.1111/j.1465-7295.2000.tb00021.x 


\section{APPENDIX}

Table A

Error correction model for the rest of the equation

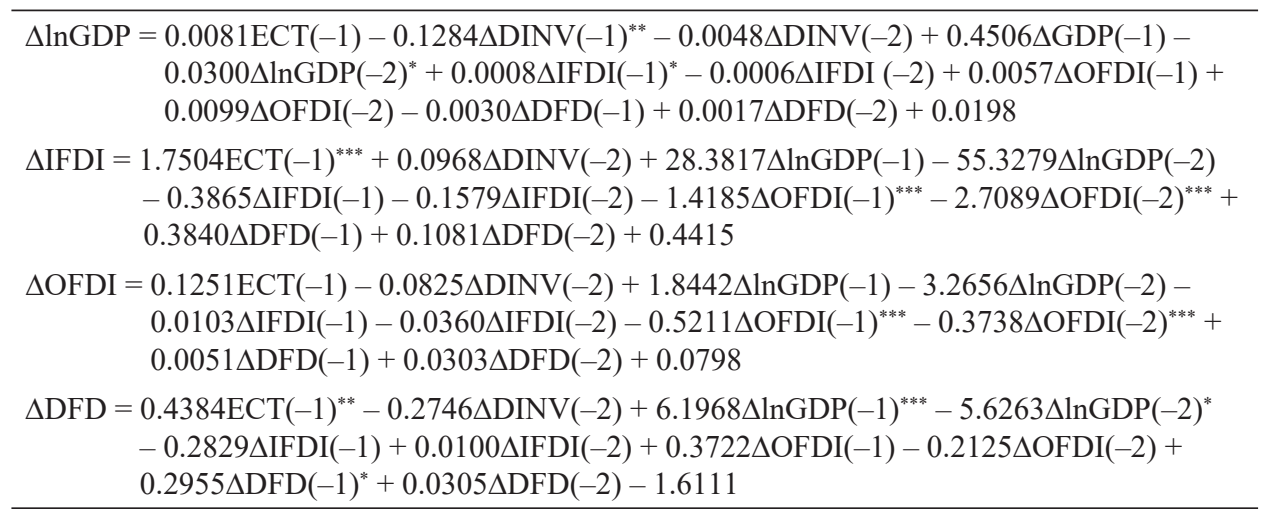

Note: ${ }^{*},{ }^{* *}$, and ${ }^{* * *}$ denote significant at $10 \%, 5 \%$, and $1 \%$ critical levels, respectively; figures in ( ) stand for lag 